Jens Tasche

Self-Regulation and Psychodynamics in Bioenergetic Analysis

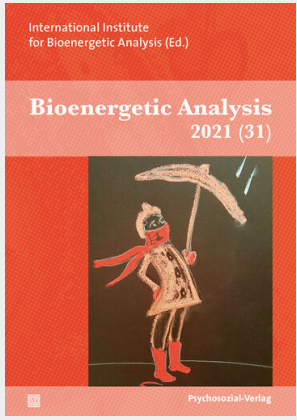

Bioenergetic Analysis

31. Volume, No. 1, 2021, Page 59-78

Psychosozial-Verlag

DOI: 10.30820/0743-4804-2021-31-59 
Reviewers for this issue:

Léia Cardenuto, Garry Cockburn, Maê Nascimento and M. Rosaria Filoni

Translators of abstracts for this issue:

Angelina Samartova (Russian), Claudia Ucros (French), Karin de Marval (Spanish), Maê Nascimento (Portuguese), Maria Rosaria Filoni (Italian), Thomas Heinrich (German) and Rebecca Jianpu Liu (Chinese)

Submissions for consideration for the next volume of Bioenergetic Analysis must be sent to Maê Nascimento (maenascimento@terra.com.br) between June $1^{\text {st }}$ and September $1^{\text {st }}$, 2021.

Bibliographic information of Die Deutsche Nationalbibliothek (The German Library) The Deutsche Nationalbibliothek lists this publication in the Deutsche Nationalbibliografie; detailed bibliographic data are available at http://dnb.d-nb.de.

2021 Psychosozial-Verlag, Gießen, Germany

info@psychosozial-verlag.de

www.psychosozial-verlag.de

\section{(C) $(1) \Theta$}

This work is licensed under the Creative Commons Attribution-NonCommercialNoDerivatives 4.0 International License (CC BY-NC-ND 4.0). This license allows private use and unmodified distribution, but prohibits editing and commercial use (further information can be found at: https://creativecommons.org/licenses/by-nc-nd/4.0/). The terms of the Creative Commons licence only apply to the original material. The reuse of material from other sources (marked with a reference) such as charts, illustrations, photos and text extracts may require further permission for use from the respective copyrights holder.

Cover image: Vincentia Schroeter, Umbrella girl (c) Vincentia Schroeter Cover design \& layout based on drafts by Hanspeter Ludwig, Wetzlar Typesetting: metiTec-Software, me-ti GmbH, Berlin, www.me-ti.de

https://doi.org/10.30820/0743-4804-2021-31

ISBN (PDF-E-Book) 978-3-8379-7809-4

ISBN (Print) 978-3-8379-8363-0

ISSN (Online) 2747-8882 • ISSN (Print) 0743-4804 


\title{
Self-Regulation and Psychodynamics in Bioenergetic Analysis
}

\section{An Approach to Advanced Training}

\author{
Jens Tasche
}

Bioenergetic Analysis • The Clinical Journal of the IIBA, 2021 (31), 59-78

https://doi.org/10.30820/0743-4804-2021-31-59

CC BY-NC-ND 4.0

www.bioenergetic-analysis.com

\section{Abstracts}

This article presents ten theses containing theoretical considerations for a postgraduate curriculum as currently tested by the Polish Society for Bioenergetic Analysis. The bioenergetic notion of the self, of affect regulation and of mental defense are modified in order to allow for psychodynamic conflict-, structure- and trauma-pathological concepts to be integrated into Bioenergetic Analysis. Among other advantages, this approach facilitates the work with structural disorders (narcissism, borderline personality disorder) in Bioenergetic Analysis.

Keywords: Bioenergetic Analysis, psychodynamics, structural disorders, affect regulation, organization of the mental defense

Auto-regulação e psicodinâmica na análise bioenergética. Uma abordagem para a formação avançada (Portuguese)

Este artigo apresenta dez teses contendo considerações teóricas para um currículo de pós graduação, como é atualmente testado na Sociedade Polonesa de Análise Bioenergética. Os conceitos bioenergéticos de self, de regulação de afeto e de defesa mental são modificadas de forma a permitir que os conceitos psicodinâmicos de conflito, estrutura e trauma - conceitos patológicos, sejam integrados à Análise Bioenergética. Esta abordagem, entre outras vantagens, facilita o trabalho com desordens estruturais (narcisismo, desordem de personalidade borderline).

Autorregulación y psicodinámica en el análisis bioenergético. Un enfoque a la formación avanzada (Spanish)

Este artículo presenta diez tesis con consideraciones teóricas para un currículum de posgrado, como el actualmente experimentado en la Sociedad Polaca de Análisis Bioenergético. Los modelos bioenergéticos de self, regulación y afecto, y de defensa mental se 
modifican de modo tal que modelos de conflictos psicodinámicos, estructura y trauma, modelos patológicos, puedan ser integrados en el Análisis Bioenergético. Entre otras ventajas, este enfoque facilita el trabajo con desórdenes estructurales (narcisismo, personalidad borderline) en Análisis Bioenergético.

Regolazione del sé e psicodinamica nell'analisi bioenergetica. Un approccio per la formazione avanzata (Italian)

Questo articolo presenta dieci tesi che contengono riflessioni teoriche per un programma post-diploma attualmente sperimentato dalla Società Polacca di Analisi Bioenergetica. I concetti bioenergetici di Sé, regolazione degli affetti e di difesa psichica vengono modificati per rendere possibile l'integrazione nell'Analisi Bioenergetica dei concetti psicodinamici di conflitto, struttura e trauma. Tra gli altri vantaggi, questo approccio facilita il lavoro bioenergetico con i disturbi strutturali (narcisismo, disturbo borderline di personalità).

\section{La régulation du soi et les processus psychodynamiques dans l'analyse bioénergétique (French)}

Cet article présente dix thèses contenant des considérations théoriques pour un programme d'études post-universitaire tel qu'il est actuellement testé par la Société polonaise d'Analyse Bioénergétique. Les notions bioénergétiques de soi, de régulation de l'affect et de défense mentale sont modifiées afin de permettre l'intégration des concepts psychodynamiques des aspects pathologiques des conflits, des structures et des traumatismes dans l'Analyse Bioénergétique. Entre autres avantages, cette approche facilite le travail avec les troubles structurels (narcissisme, trouble de la personnalité limite) dans l'analyse bioénergétique.

Selbstregulation und Psychodynamik in der bioenergetischen analyse. Ein Ansatz zur Fortbildung (German)

Dieser Artikel enthält zehn Thesen mit theoretischen Überlegungen zu einem postgradualen Lehrplan, wie er derzeit von der Polnischen Gesellschaft für bioenergetische Analyse getestet wird. Der bioenergetische Begriff des Selbst, der Affektregulation und der mentalen Abwehr wird modifiziert, um die Integration psychodynamischer konflikt-, strukturund traumapathologischer Konzepte in die bioenergetische Analyse zu ermöglichen. Dieser Ansatz erleichtert unter anderem die Arbeit mit strukturellen Störungen (Narzissmus, Borderline-Persönlichkeitsstörung) in der bioenergetischen Analyse.

\section{Саморегуляция и психодинамика в биоэнергетическом анализе. Подход к продвинутому обучению (Йенс Tame) (Russian)}

В статье представлены десять тезисов с теоретическими идеями для аспирантского учебного плана, который сейчас тестируется Польским обществом биоэнергетического анализа. Биоэнергетические концепции "я", регуляции аффекта и ментальных защит были модифицированы, чтобы сделать возможной интеграцию психодинамических конфликтных, структурных и травмо- 
патологических концепций в биоэнергетический анализ. Помимо других преимуществ, этот подход облегчает работу со структурными расстройствами (нарциссизм, пограничное расстройство личности) в биоэнергетическом анализе.

躯体动力分析中的自我调节和心理动力。高阶训练方式 (Chinese) 这篇文章呈现了波兰躯体动力分析协会近期在思考的关于培训毕业后持续教育的 10 个理论重点。 其对躯体动力分析中的自体、情感调节和头脑防御概念都予以修正，好将心理动力冲突、结构和 创伤病理理念整合到躯体动力分析框架中。此举有多种优势，其一是它促进了躯体动力分析中结 构障碍的治疗(自恋，边缘人格障碍)。

\section{Introduction}

The self does not provide support but sends us on a journey into the unknown. ${ }^{1}$

\section{Rüdiger Safranski}

At the suggestion of my colleague Barbara Antonowicz-Wlazinska, the Polish Society for Bioenergetic Analysis (PGBA) commissioned me at the beginning of 2017 to develop a concept for a postgraduate advanced training. Like many other bioenergetic training institutes, the PGBA was and still is confronted with the problem that the transfer of bioenergetic knowledge as acquired in the training to become a Bioenergetic Analyst into an effective body-psychotherapeutic practice is made difficult by the fact that not all training candidates have a well-founded general psychodynamic or psychotherapeutic basic qualification - or do not feel confident to adequately combine their knowledge with the bioenergetic method. In response to this situation, since 2018, the PGBA has been offering a fouryear advanced training entitled Self-Regulation and Psychodynamics in Bioenergetic Analysis to all members who have completed their Certified Bioenergetic Analyst (CBA) training. Together with my colleagues Alice Moll, Carsten Holle and Dr. Reinhard Weber-Steinbach, it has since then been my pleasure to support the Polish colleagues in acquiring an extended methodological body-therapeuticpsychodynamic qualification - in terms of both theoretical knowledge and the related therapeutic attitude.

The curriculum for the advanced training, which I developed with the support of Carsten Holle and Reinhard Weber-Steinbach, understands the bioenergetic

1 All exact quotes in this text are translated from the respective publications in German. Therefore, some inconsistencies might arise in the case of quotes that have originally been formulated in English. 
method as the central approach to all body-psychotherapeutic work, but also takes into account that the drive-economical model underlying Bioenergetic Analysis has its limitations and cannot represent today's entire disease panorama in a meaningful way. In order to provide a theoretical and methodological foundation for bioenergetic work with structural deficits, such as narcissistic or borderline personality disorders, the curriculum aims at a psychodynamic extension of Bioenergetic Analysis, which in particular makes it possible to include conflict-, structure- and trauma-pathological models as used in Psychoanalysis. Based on this aim, the topic of bioenergetic affect vitalization will be examined primarily in the complex context of affect regulation and the defense processes required for regulating affects. In addition, the advanced training wants to convey the necessary competence for analyzing and interpreting bioenergetic processes on the basis of a developmental-psychological/developmental-psychopathological understanding of disorders, very much in line with the statement of the neuropsychoanalyst Allan N. Schore, according to which at present "all important theorists base their clinical models on developmental concepts" (Schore, 2003, p. 28).

One of the main challenges for the lecturers of the advanced training consists of preparing and imparting the psychoanalytical knowledge in such a way that concrete body-therapeutic procedures can be justified or derived from it. While today's psychoanalytical concepts explicitly emphasize the importance of working with affects and also recognize the role that the body plays in the development of - especially "early" - disorders, contemporary Psychoanalysis shows no willingness to extend its psychodynamic defense theory by including the manifold defense patterns beyond psychosomatic disorders which occur in or are expressed by the body. Considering that Anna Freud stated already in 1936 - with explicit reference to Wilhelm Reich - that "bodily postures such as stiffness and rigidity, peculiarities of the being such as a stereotypical smile, sneering, ironic and haughty behavior" are permanent defensive phenomena (A. Freud, 1991, p. 28), this lack of willingness can only be noted with great regret.

\section{Ten Basic Theses for Psychodynamic Thinking in Bioenergetics}

Although Psychoanalysis and Bioenergetic Analysis (still) differ in their views on body-related defense patterns, they are largely linked by common basic theoretical assumptions. In particular, both approaches share the basic assumption of a psychodynamic unconscious which helps to regulate intrapsychic as well as interpersonal conflicts and whose dysfunctionality forms the basis for psychopathologies. In order to facilitate the integration of psychoanalytical knowledge for the participants of the advanced training, a total of ten basic theses were developed on 
the basis of these common features, with the help of which the learned "bioenergetic thinking" can be extended in the direction of psychodynamic thinking in Bioenergetics.

\section{First Basic Thesis}

Today, most psychotherapeutic methods having been developed in the last 150 years share the firm belief that mental disorders are connected with:
(a) the body
(b) functional/dysfunctional relations to meaningful others
(c) the capacity to regulate arousal.

Although Psychoanalysis certainly does not pay much attention to bodily processes in the context of the development of psychopathologies, it does not deny their existence either. Phyllis and Robert Tyson, for example, already dealt with Freud's famous sentence "The ego is first and foremost a bodily ego" in their book Psychoanalytical Theories of Development (published 1990 in German), and they pointed out that a person's self-perception can only develop once "a sense of the body comes together" (Tyson \& Tyson, 2012, p. 305f.). Also, the psychoanalyst Michael Ermann mentions that early disorders are characterized by the fact that the experiences which are significant for the disorder are predominantly represented in a bodily-affective way - as an archaic self - and do not yet have a semantic structure (Ermann, 2014, p. 106). And for Allan N. Schore, it is clear that the ego only exists in the context of a holistic psychobiological organism (Schore, 2003, p. 217).

It is mainly due to Peter Fonagy and Mary Target that the findings of attachment theory were re-integrated into the corpus of psychoanalytical theory (Fonagy \& Target, 2003, pp. 312-341) - which triggered a decisive paradigm shift. Today, Bioenergetic Analysis and Psychoanalysis share the conviction that the unfinished self urgently needs a supportive environment in order to realize its innate psychophysical potential for development.

While there is still a fairly broad consensus between Bioenergetic Analysis and Psychoanalysis with regard to the developmental-psychological/developmentalpsychopathological significance of the body and of object relations, substantial differences prevail in the respective views when it comes to the development of the ability to regulate affects. From Schore's point of view, both clinical studies and research models show the importance not only of affects, but also of affect regulation in the psychological and biological development (Schore, 2003, p. 169). According to Psychoanalysis, a child acquires her ability to regulate affects in a very complex developmental process of self-, object- and interactional 
representations. In contrast, Bioenergetic Analysis assumes that the biological self of a human being has a high degree of resilience and extensive self-regulating healing powers. Accordingly, the assessment of the therapeutic procedure differs with regard to affect regulation: While Bioenergetic Analysis assumes that the necessary cognitive, social and regulatory skills can be acquired through an interplay of basic bioenergetic concepts (such as grounding, self-expression or containment) and the work with feelings or involuntary body movements as soon as the affect which had hitherto been frozen in the musculature can enter the consciousness (Moll, 2018, p. 41f.), Psychoanalysis sees the therapeutic task rather in raising the unconscious affect, which was neither interactively regulated nor internally represented during the child's development, from a primitive, pre-symbolic, sensorimotor experience to a mature, symbolic level of representation in order to achieve an improved emotional control (Schore, 2003, p. 54).

In narcissistic and borderline personality disorders, the different views of Psychoanalysis and Bioenergetic Analysis with regard to the ability to regulate affects are particularly noticeable. Today, these disorders are understood in Psychoanalysis as structural disorders and can be successfully treated on this basis. They are also strongly represented among the clients of Bioenergetic Analysts, where they cause great difficulties especially for professional newcomers among the CBA graduates, since for these disorders the learned bioenergetic methodology can be turned only very inadequately into an effective practice.

\section{Second Basic Thesis}

Every mental disorder also manifests itself in the body, and it goes along with a restricted ability to regulate affects and object relations.

"The spirit of a self-experiential body-psychotherapy consists [...] of guiding a person towards discovering, experiencing and learning to regulate himself/herself holistically with regard to his/her experiential processes and actions" (Geuter, 2019 , p. 80). In order to actually implement this spirit, the affective experiences that are made accessible in the bioenergetic processes must be examined on the physical, social and psychological level. If one assumes that the muscular blockages are unconscious psychobiological defense strategies, these are to be understood as a successful adjustment strategy (Schore, 2003, p. 93) which influences the regulation of affects and object relations in a complex way. Beyond a drive-economic explanatory model, bodily affective processes must therefore be investigated primarily with regard to their significance for self-regulation. Thereby, the question "To what extent must the bodily suppression of affects be understood as an unconscious or perhaps even deliberate act of adjustment in order to compensate for possible structural deficiencies?" is of particular impor- 
tance. After all, e.g., aggressive affects as activated in bioenergetic processes can only be meaningfully integrated into a self-experience if the ability to modulate or downregulate aggression via mental processes has already been acquired to a sufficient degree.

In contrast to the classical bioenergetic teaching, the theoretical approach of the advanced training is based on a self that can show serious developmental deficits and compensate for possible deficiencies regarding the ability to mentally regulate emotions and object relations by physical blockages. In her understanding of the self, the advanced training is guided by four basic questions which Schore formulated very aptly with reference to Heinz Kohut (Schore, 2003, p. 150):

$>$ How do early relational affective transactions with the social environment facilitate the emergence and development of the self? (self-development)

$>$ How are these experiences internalized into mature, self-regulating structures? (structure-formation process of the self)

$>$ Why do early deficits in the self-structure lead to later self-pathologies? (psychopathogenesis)

$>$ How can the therapeutic relationship bring about a healing of the self? (effect of the psychoanalytic change)

\section{Third Basic Thesis}

In this context, the regulation of both affects and object relations are organismic processes and therefore also bodily events. Hence, any purposeful treatment of mental disorders must take the somatic base of affect regulation and the regulation of object relations into account.

Today, the view that self-development and structure-forming processes are organismic and social processes can be considered generally accepted. As Georg Groddeck had already formulated: "The unconscious is the actual mediator between the body and consciousness, perhaps the long sought 'missing link" (Groddeck, quoted in Schore, 2003, p. 71). And for Erik Erikson, "a human being $[\ldots]$ is at every moment an organism, an ego and a member of a society, and thus included in all three organizational processes" (Erikson, 2005, p. 29). Peter Fonagy also states:

"Today, it can be assumed with virtual certainty that the interactions between infants and their primary attachment figures in a very early developmental stage become precursors of those neurobiological structures which as representations shape the later experiences to an essential degree" (Fonagy, quoted in Schultz-Venrath, 2013, p. 120). 
Sigmund Freud understood the drive - which also forms the basis of the bioenergetic character theory within the framework of the psychoanalytical drive theory - as a limit-concept between the mental and the somatic level. Based on this, the neuroscientist Antonio Damasio describes emotions as "expressive manifestations of the drives" (Damasio, quoted in Schultz-Venrath, 2013, p. 130), and Schore considers it necessary, on the basis of recent psycho- and neurobiological studies, to reintroduce the drive as a central concept in psychoanalytic theory (Schore, 2003, p. 44). Being a self-psychologist, he also demands: "The biological organism, the body, should be built into the core of self-psychology" (ibid., p. 154).

With the idea of affect-related processes being rooted in a drive that connects body and mind and whose regulation is acquired by interactional means via the development of intrapsychic instances, the advanced training is based on a psychodynamic developmental-psychological understanding that strongly facilitates the access to structural disorders. This can only happen in the context of a "two-person psychology" which wants to and is also able to look at the selfexperiential events of Bioenergetic Analysis from the perspective of affect regulation/regulation of object relations. The goal of the body-therapeutic work is then "to exert influence on archaic self-states which have brought the development to a standstill, and to enable new relationship experiences" (Ermann, 2014, p. 106). This includes the conviction that "all processes that ultimately lead to therapeutic changes in the patient's soul are triggered by events in a two-person relationship, i. e., by something that basically happens between two people and not only within one of them" (Balint, 2014, p. 18).

\section{Fourth Basic Thesis}

Mental disorders can be understood as regulatory problems at the level of affects, of the body and of object relations.

Problems regarding the regulation of self-esteem, the successful shaping of interpersonal relationships and the affective impulse control are often rooted in a personality disorder which can also be understood as a structural disorder. The structure of the self is made to organize affects, behavior and object relations. This organized vitality is understood as a biophysical event, which is recorded, among others, in structural (AK-OPD, 2006) or mentalizing (Fonagy et al., 2004) abilities in Psychoanalysis. Accordingly, OPD 2 (Operationalized Psychodynamic Diagnostics OPD-2) conceives these abilities in four dimensions (AKOPD, 2006, p. 118):

$>$ competence for self- and object perception;

$>$ self-regulation and regulation of object relations; 
$>$ ability for emotional communication both internally and externally;

$>$ ability for inner and outer attachment.

Peter Fonagy and his colleagues, on the other hand, understand mentalization as a social-cognitive ability to "imagine mental states in one's own self and in other people" (Taubner, 2016, p. 15). Thereby, Fonagy et al. assume that the inability to mentalize is a structural deficit (Holmes, 2006, p. 82).

In the context of intensive self-experiential bioenergetic processes, it is unfortunately not always easy to judge if a client's mental abilities are sufficiently developed in order to integrate the vitalized affects into the self. After all, affective-emotional processes are often easier to provoke with the help of bioenergetic techniques in clients who are affected by structural deficits than is the case with mentally more mature personalities. Here too, the bioenergetic work may well be accompanied by an energetic discharge and emotional relaxation. Apart from that, however, the experienced process cannot be used for continuous personal growth in these cases. For this reason, the advanced training wants to enable the participants to understand bioenergetic processes also with regard to the structural and mentalizing events that are reflected in them, in order to be able to take up topics such as self-expression in the as-if mode, narcissistic self-regulation or deficiencies in self- and object perception in the context of their body-therapeutic work. In this way, therapeutic possibilities for the post-maturing of structural and mentalization deficits are pointed out.

\section{Fifth Basic Thesis}

The ability to experience or to express affects can be overregulated, underregulated or dysregulated.

The central goal of Bioenergetic Analysis is to support the client in having a self-experience that is based on access to his or her own feelings. In Bioenergetic Analysis, this goal is strived for by increasing the level of experience: The suppressed affect should be allowed, perceived, endured and expressed. This approach provides an excellent means for conceptualizing the work with clients who have a sufficient mental and structural competence and who - according to the bioenergetic character theory - suffer from an overmodulation or inhibition of their ability to experience affects.

From the perspective of the bioenergetic character theory, the dissolution of bodily affect blockades is the essential basis for the activation of self-regulating processes, which in turn stimulate the healing powers of the human organism and thus enable a more appropriate handling of one's own experienced and felt history. In this therapeutic understanding, defense patterns are primarily understood 
as obstacles on the path to human growth. This healing path has been followed in countless bioenergetic treatments worldwide over the last 60 years and has helped many people to reach a deeper connection with their own feelings, a higher capacity for experience and a greater self-acceptance.

However, Wilhelm Reich, in his book Der triebhafte Charakter (English title: The Impulsive Character) published in 1925, already dealt with psychological problems that are not characterized by an over- but an under-modulation of the affects. In spite of this role model, Bioenergetic Analysis has unfortunately not yet developed any really conclusive concepts for coping with emotional flooding as well as with problems related to a distorted perception of the self and others. This is probably also due to the fact that such disorders are difficult to explain within the framework of the image of man on which Bioenergetic Analysis is based, which is characterized by a high degree of self-regulatory competence and regards a conflict-free experience of affects as an ideal.

To date, Bioenergetic Analysis has not succeeded in integrating a psychodynamic understanding of structure as well as structure-related pathologies into its treatment concept. As a result, there is a danger that essential disorders related to attachment processes will not become the subject of bioenergetic therapy, nor will the maturation of structural competencies that enable the integration of bioenergetically vitalized affects into the self - and thus the corresponding continuous experience of affects - in the first place. This lack is what the advanced training aims to remedy. In addition, it wants to show that the ability to regulate affects can be impaired in many ways. Perhaps biographical experiences - despite all revived anger - rather need to be acknowledged and mourned so that the transition to the next maturation phase can be successful. Also in the context of a hysterical defense, a deepened self-awareness is not possible, just as in the case of a fixation on "autistic-cathartic" affective experiences, which cannot become part of relationship- and attachment-experiences due to the narcissistic personality pattern.

\section{Sixth Basic Thesis}

Problems related to the regulation of affects and object relations can manifest themselves as ego-syntonic or as ego-dystonic disorders.

"Unlike ego-dystonic disorders (e. g., a fear of flying), people with ego-syntonic disorders are not confronted with a symptom that they experience as foreign. Instead, it comes to a special shaping of the character [...]. The concerned persons experience these characteristics, for example a strong neediness or a great submissiveness, not as alien or disturbing, but as an expression of their personality" (Tasche, 2016, p. 17). 
This does not mean, however, that ego-syntonic disorders are not connected with experiences of suffering - but these experiences are normally understood as belonging to the self or as suffering from the world, similar to chronic physical illnesses ("Everyone else is better off.").

The first descriptions of ego-syntonic disorders were given by Karl Abraham and Wilhelm Reich. Similar to Abraham, Reich was of the opinion that patients "can have character deformations that inhibit the psychoanalytic treatment. Reich was also of the opinion that there is no clear distinction between symptom neuroses and character neuroses" (Sharaf, 1994, p. 97). Reich combined this conviction with a great interest in the non-verbal behavior of his patients. On the basis of Freud's driveeconomic theory, he also tied in with Freud's original view that not only remembering but the full revival of stressful childhood situations in their entire emotional expression is necessary to dissolve character neuroses and symptom neuroses (ibid., p. 100). These findings led Reich to the core idea of body psychotherapy:

"Symptom neuroses and character neuroses are based on a blockage of the libido energy, which always manifests itself in a bodily-muscular way. Now if the energetic blockage could be dissolved, the neurotic disorder would no longer have a basis. The symptoms would have to dissolve, the defense against the emotional arousal would have to disappear, and the client would be cured" (Tasche, 2016, p. 17).

However, this energetic self-experiential concept presupposes that the person has no difficulties in regulating the affective arousal as soon as the defense against the affects is abandoned.

The advanced training would like to provide new perspectives on bodypsychotherapeutic events by showing that both ego-syntonic and ego-dystonic disorders must not be understood as affect blockades but as affect regulation disorders. In this understanding, the original defense against the affect can only be abandoned if the concerned person has the necessary structural abilities to regulate the revived affect both introspectively and interactively in a socially adequate way. Accordingly, the therapeutic goal of a maturing mental defense must be integrated into the therapeutic process of Bioenergetic Analysis.

\section{Seventh Basic Thesis}

When it comes to a body-psychotherapeutic treatment of mental disorders, it is not sufficient to classify the disorders. Much rather, the disorders must also be understood.

In more recent approaches to Psychoanalysis - especially in object relations theory and self-psychology - it is assumed, in accordance with the understanding of heal- 
ing in Bioenergetic Analysis, that numerous mental disorders are due to deficits in childhood and that these deficits can be compensated for in therapy - i.e., in the relationship with the therapist - through corrective emotional experiences. With this new conception, the therapeutic attitude of the analyst has changed in Psychoanalysis: The principle of abstinence, which had often been applied very rigidly, was replaced by a functional principle according to which "the analyst has to decide, depending on the situation, whether, to what extent and in what form he or she responds to the wishes and desires of the patient, in order to subsequently examine how the patient processes his or her behavior" (Ermann, 2014, p. 121).

In a very similar sense, the Bioenergetic Analyst enters the field of the therapeutic relationship. In doing so, he learns to understand the client on an energetic, bodily, developmental-psychological and intersubjective level. For a Bioenergetic Analysis which is aware of its anchoring in Humanistic Psychology, this understanding means much more than a diagnosis marked by abstinence. Much rather, it is a learning experience which Rollo May has very aptly described by the following Husserl quote:

"Learning is not the accumulation of fragmented knowledge. It is a process of growth in which the learner develops through the act of cognition and thereby acquires the ability to recognize ever more and ever more complex interrelationships, and the objective increase in complexity runs parallel to the subjective increase in competence" (Edmund Husserl, quoted in May, 1988, p. 221).

This experience describes a joint learning of the Bioenergetic Analyst and the client in an interpersonal field, which is characterized by curiosity, mutuality and the willingness to correct oneself. The prerequisite for this psychodynamic form of work is a therapeutic alliance that can be characterized by:

$>$ common goals,

$>$ a recognition of the respective tasks that the client and the therapist must perform, and

$>$ the activation of the attachment system (William, 2006, p. 316).

However, the "therapist has a special responsibility for the treatment and a special competence to lead the process. This results in an asymmetry in the structure of the therapeutic relationship, which naturally influences the relationship and process design. The essentially equal participation of both subjectivities in the encounter, i. e., the symmetry of the contents, prevails nevertheless" (Ermann, 2014, p. 127).

The activation of the attachment system is of special importance whenever the therapeutic task is to support structural changes in order to "develop affects in their earliest form, where they are experienced as bodily sensations, [...] into subjective states that can gradually be articulated verbally" (Schore, 2003, p. 127). 
"[Martin] Buber insisted that human life is a life in dialogue [...] - he claims that we can only recognize our self in dialogue" (May, 1988, p. 152). In this sense, the advanced training wants to convey an attitude according to which Bioenergetic Analysis continues to be understood as an expression of Buber's encounter paradigm, but where participants are also encouraged to flexibly adapt their therapeutic knowledge and role to a specific therapeutic situation.

\section{Eighth Basic Thesis}

A distinction into character-, conflict-, structure- and trauma-related pathologies is helpful both for gaining a more profound understanding of mental disorders and for the related therapeutic processes. Despite the differing theoretical frameworks that these disorder models refer to, the models can be readily integrated into the bioenergetic practice.

As already mentioned, Bioenergetic Analysis wants to help its clients to a selfexperience based on access to their own feelings. This concern finds its expression in the well-known guiding principle "You are your body". But this approach does not always lead to personal growth, maturation or healing. For example, it is quite possible that unconscious anger affects are revived during bioenergetic processes without the client having sufficient abilities to accept these affects as an expression of her own self and to modulate them in such a way that she can include them into her social contacts in an adequate form.

In Psychoanalysis, a psychodynamic understanding of disorders has been established that distinguishes between conflict-, structure- and trauma-related pathologies - especially due to Gerd Rudolf, co-founder of the working group "Operationalized Psychodynamic Diagnostics" and one of the thought leaders of a comprehensive psychodynamic competence to act. An opening-up of the bioenergetic teaching towards this new approach could help to differentiate the understanding of bioenergetic experiences in clients who primarily suffer from disorders other than character-related pathologies.

The greatest difficulty in integrating conflict-, structural- and trauma-pathological considerations into the framework of Bioenergetic Analysis lies in the different perspectives on defense processes. While Bioenergetic Analysis tends to view psychological and bodily-affective defense processes as obstacles on the path to liberating self-insight, Psychoanalysis views defense mechanisms as an indispensable element of the ability to regulate affects. From the point of view of Psychoanalysis, however, these mechanisms can also contribute to the pathogenesis, namely in the case of excessive rigidity or dysfunctionality (AK-OPD, 2006, p. 25). In Psychoanalysis, therefore, the alternative to frozen defense mechanisms - as the body armor is understood by Bioenergetic Analysis - is not the 
general abandonment of defense, but a mature defense which is capable of raising affects from a primitive, pre-symbolic, sensorimotor experience to a mature, symbolic level of representation (Schore, 2003, p. 54).

\section{Conflict-Related Pathology}

In the classical conflict theory of Psychoanalysis, mental defense is considered in connection with the three psychic instances of id, ego and super-ego. The aim of the defense is to maintain the mental balance. Conflicts can arise between the instances, but also within each instance. In these fields of conflict, affects and impulses that are connected with negative experiences/ideas are kept away from conscious experience in order to enable the most positive self-experience possible. In the context of conflict theory, it is thereby assumed that the failed resolution of a conflict leads to psychological symptoms (fears, compulsions, depressions, psychosomatic stress).

"The therapeutic approach to conflict-related pathologies consists primarily in making the unconscious (original needs, defense, moral imperatives) conscious and thus accessible through interpretation, in order to enable a more mature approach to the underlying thematic complexes (e.g., closeness or supply wishes, anger, sexuality)" (Dürich, 2017). In this understanding, the therapeutic goal is primarily achieved through insight into the psychological conflict and the associated self-knowledge.

\section{Structure-Related Pathology}

The structural theory of Psychoanalysis takes up Michael Balint's concept of the basic fault. Although this concept has historically developed from ego-psychology, self-psychology and object relations theory - i. e., from approaches originally assigned to conflict theory -, it primarily considers developmentalpsychological processes that biographically precede the management of conflicts between the psychological instances. From this perspective, structurerelated pathologies arise when stressful environmental factors impede the development of a psychological structure. These deficits then impair the ability of the concerned person to cope with internal conflicts and to bear external stresses. Depending on the severity of the deficit, structural deficits can lead to pathologies such as borderline personality disorder, narcissistic disorder, burnout syndrome, but also to psychological symptoms or character deformations.

The procedure proposed in Psychoanalysis for structure-related pathologies "consists primarily in taking over auxiliary ego functions, which are to be stimu- 
lated and internalized by the therapeutic process" (Dürich, 2017). The aim of the therapeutic intervention is the (post-)maturation of self-functions.

\section{Trauma-Related Pathology}

"From a clinical perspective, a distinction is made between a mono-trauma in adulthood (type-1-trauma, acute traumatization), which is defined as a situation of extraordinary threat with catastrophic proportions that would cause deep despair in almost any person, and a cumulative trauma in childhood (type-2-trauma, complex traumatization), which mainly includes attachment traumas such as psychological or physical abuse by relevant attachment figures. An additional factor is the experience of complete helplessness and powerlessness in a lifethreatening situation" (Dürich, 2017).

"These events can trigger extreme stress in a person and create feelings of helplessness or horror. The anxiety- and stress-related tension caused by these events can subside on its own for the majority of those affected. [...] In special cases, however, if this increased stress-related tension persists for a longer period of time and there is no possibility to process the experiences, very intense psychological symptoms may develop" (German Wikipedia on Trauma [Psychology], 2020).

Regarding type-2-trauma, classical attachment theory and object relations theory assume that early traumatic experiences become the basis for corresponding relationship expectations. Traumatizations in later life then reactivate these expectations and interact with them (Allen et al., 2015, p. 485). From the perspective of the mentalization approach, trauma can be described as a freezing or blocking of psychological development processes - the client is stuck in the trauma.

"Such a 'sticking' has two important consequences. First, the connection between the pre-traumatic self and the post-traumatic self is severed. The affected person is now defined solely by the trauma, which is played out over and over again. Any resilience that she may have had prior to the event has been lost. The second point is related to the first. Paradoxically, the 'sticking' represents an avoidance - an avoidance of thinking about the trauma in all its complexity and, consequently, of the need to confront the painful affect" (ibid., p. 497).

The approach to trauma-related pathologies mainly consists in restoring neurobiological processing skills. For this purpose, special methods such as EMDR or Psychodynamic Imaginative Trauma Therapy according to Luise Reddemann are recommended. 


\section{Ninth Basic Thesis}

The understanding of character, conflict, structure and trauma are not competing concepts, but can be considered as different perspectives that the Bioenergetic Analyst may take. These perspectives may be helpful for adapting the therapeutic process to the individual experience and the capacities of a client.

Gerd Rudolf describes the goals of therapeutic actions as follows: "The ability to be able to live in fulfilled relationships, to make better use of one's own strengths, to maintain a realistic sense of self-esteem, to communicate better with others, to be more emotionally alive, to be able to shape one's life more freely and flexibly" (Rudolf, 2010, p. 15). In order to achieve these goals, it seems helpful if the Bioenergetic Analyst can adopt different perspectives on the therapeutic process. However, all four above-mentioned approaches are complex intellectual models which more or less claim to be able to explain and treat all the psychopathologies that occur within the framework of their model. While Bioenergetic Analysis in the tradition of Reich and Lowen assumes that all mental disorders can be treated within the framework of the energetic paradigm, conflict psychology has developed a competent approach to explain early disorders in the form of the egopsychological concept of developmental lines - such as defense mechanisms, overcoming fear or the super-ego - that can derail (Fonagy \& Target, 2003, p. 121). Conversely, some structure- and mentalization-theorists give the impression that their therapeutic methods make all previously developed methods superfluous. The trauma-therapeutic approach, which enjoys great popularity in psychotherapeutic clinics and practices due to its neurobiological model concepts, also bears the danger that the burdens of clients are quite uncritically attributed to childhood traumas and only inadequately treated by neglecting the conflict- and structurerelated perspectives. "A study by Komo (2009) showed that only in 25 percent of the patients whose disorders were attributed to post-traumatic stress and who were treated trauma-therapeutically according to the official German psychotherapy guidelines, the symptom and event criteria of a traumatization were fulfilled" (Dürich, 2017). Rudolf also believes: "An expansion of trauma-therapeutic methods within the psychodynamic treatment practice is rightly regarded with concern if it is at the expense of the necessary conflict- and structure-related work" (ibid.).

Ultimately, every problem that arises in therapy can probably be viewed and dealt with from different directions. From the point of view of a Bioenergetic Analysis which embraces a psychodynamic understanding, it is decisive that the topics of access to affects and affect regulation are kept equally in the focus of the body-psychotherapeutic work. In this sense, the advanced training aims at enabling the participants to adopt character-, conflict-, structure- or traumapathological perspectives on the basis of a complex and competent psychodynam- 
ic understanding, in order to be able to tune into the therapeutic situation/client as optimally as possible.

\section{Tenth Basic Thesis}

This is why the Bioenergetic Analyst toggles between the different perspectives in accordance with his assessment of the current issue to be treated. In terms of the therapeutic process, he goes by an understanding of liberation (for the character-related pathology), of insight (for the conflict-related pathology), of maturation (for the structure-related pathology) or of restoration (for the trauma-related pathology).

The advanced training aims at helping the participants expand their ideas beyond the traditional goals of the bioenergetic work - such as emotionally correcting experiences or cathartic liberation - towards a psychodynamic understanding, in order to offer a knowledge-based alternative to those aspects of the bioenergetic work which are classified as intuitive and experimental. Being aware that a large proportion of clients in bioenergetic practices suffer from disorders that have character-, conflict-, structure- or trauma-pathological elements, the advanced training assumes that liberation, insight, maturation and restoration are integrative elements of any organismic healing process. These elements must be identified and addressed in the respective therapeutic situation. A Bioenergetic Analysis that understands itself psychodynamically can therefore be characterized by principles such as vitalization, support, interpretation, confrontation and psychoeducation.

In this context, the processes of transference and countertransference are of particular importance. Thus, the Bioenergetic Analyst activates transference processes and certainly takes active roles that serve a corrective emotional experience. In doing so, however, he is able to "inhibit his natural tendency to react particularly compassionately to the psychological suffering of the client" (Bateman \& Fonagy, 2015, p. 93) and to distance himself emotionally in order to support an autoregulatory, mentalizing processing of affects in the client. In this context, countertransference is defined as "empathic reactions that arise from the emotional resonance of the therapist with the client. They are related to the affective attunement, to empathy and mirroring, as well as to emotional identification, which are not to be regarded as mere projections, but are part of every relationship" (ibid., p. 103).

\section{Current Status of the Advanced Training}

The advanced training is structured in modules. In approximately 290 academic hours, bundled in 20 weekend modules, the essential findings of attachment re- 
search, ego-psychology, object relations theory, the mentalization approach and relational Psychoanalysis are taught in the context of a body-oriented self- and action-oriented experience. By now, the first participants have completed half of the offered modules. Unfortunately, an actual evaluation of the training is not possible, but at the end of each module the participants fill out a feedback form, which also asks for the practical relevance of the taught contents. Through the opinion thus determined, those responsible for the advanced training feel confirmed in their goals and efforts.

The modules are held in English with Polish translation. The written curriculum is available in German, English and Polish from the author. The advanced training is internationally open to all bioenergetic therapists who have completed the necessary training units for CBA certification. If you are interested in participating, please contact the following colleagues: Barbara Antonowicz (b.antonowicz@wp.pl) for contact in German and Polish; and Darius Zawrzykraj (dariusz.zawrzykraj@gmail.com) for contact in English.

\section{References}

Allen, J.G., Lemma, A., Fonagy, P. (2015). Trauma. In: Bateman, A.W., Fonagy, P. (Eds.), Handbuch Mentalisieren (English title: Handbook of Mentalizing). Gießen: PsychosozialVerlag.

Arbeitskreis OPD (2006). Operationalisierte Psychodynamische Diagnostik OPD-2 (translated title: Operationalized Psychodynamic Diagnostics OPD-2). Bern: Hans Huber.

Balint, M. (2014). Therapeutische Aspekte der Regression - Die Theorie der Grundstörung (English title: The Basic Fault - Therapeutic Aspects of Regression). Stuttgart: Klett-Cotta.

Bateman A. W., Fonagy, P. (2015). Das Grundmodell in der Einzelpsychotherapie (translated title: The Basic Model in Individual Psychotherapy). In: Bateman, A. W., Fonagy, P. (Eds.), Handbuch Mentalisieren (English title: Handbook of Mentalizing). Gießen: PsychosozialVerlag.

Buber, M. (1995). Ich und Du (English title: I and Thou). Stuttgart: Reclam Verlag.

Dürich, C. (2017). Konflikt-, Struktur und Traumapathologie (translated title: Conflict-, Structure- and Trauma-Pathology). In Analyze that - Ein psychoanalytischer Blog [Weblog] (created on Feb. $7^{\text {th }}$, 2017). Online publication: www.analyze-that.de/konflikt-struktur -und-traumapathologie (retrieved February 9, 2020).

Erikson, E. H. (2005). Kindheit und Gesellschaft (English title: Childhood and Society). Stuttgart: Klett-Cotta.

Ermann, M. (2014). Der Andere in der Psychoanalyse (translated title: The Other One in Psychoanalysis). Stuttgart: Kohlhammer.

Fonagy, P., Gergely, G., Jurist, E. L., \& Target, M. (2004). Affektregulierung, Mentalisierung und die Entwicklung des Selbst (English title: Affect Regulation, Mentalization and the Development of the Self). Stuttgart: Klett-Cotta. 
Fonagy, P., \& Target, M. (2003). Psychoanalyse und die Psychopathologie der Entwicklung (English title: Psychoanalytic Theories - Perspectives from Developmental Psychopathology). Stuttgart: Klett-Cotta.

Freud, A. (1991). Das Ich und die Abwehrmechanismen (English title: The Ego and the Defense Mechanisms). Frankfurt am Main: Fischer Taschenbuch.

Geuter, U. (2019). Praxis Körperpsychotherapie (translated title: How to Practice Body-Oriented Psychotherapy). Wiesbaden: Springer.

Holmes, J. (2006). Mentalisieren in psychoanalytischer Sicht - Was ist neu? (translated title: Mentalizing from a Psychoanalytical Perspective - What is New?). In J.G. Allen \& J.G. Fonagy, P. (Eds.), Mentalisierungsgestützte Therapie (English title: Handbook of Mentalization-Based Treatment). Stuttgart: Klett-Cotta.

Holmes, J. (2012). Sichere Bindung und Psychodynamische Therapie (English title: Exploring in Security). Stuttgart: Klett Cotta.

Lowen, A. (1998). Bioenergetik - Therapie der Seele mit dem Körper (English title: Bioenergetics - Healing the Soul by Working with the Body). Reinbek: Rowohlt Taschenbuch.

May, R. (1974). Liebe und Wille (English title: Love and Will). Bergisch-Gladbach: Andreas Kohlhage.

Moll, A. (2018). Wozu so eine komplizierte Theorie, wenn wir doch direkt mit dem Körper arbeiten können? Mein Weg als Bioenergetik-Therapeutin zum Mentalisierungskonzept (translated title: Why such a complicated theory if we can work directly with the body? My path as a Bioenergetic Analyst towards the mentalization concept). In J. Tasche \& R. Weber-Steinbach (Eds.), Bioenergetik als mentalisierende Körperpsychotherapie (translated title: Bioenergetics as a Mentalizing Body-Oriented Psychotherapy). Göttingen: Vandenhoeck \& Ruprecht.

Reich, W. (2019). Der triebhafte Charakter (English title: The Impulsive Character). Inktank Publishing.

Rudolf, G. (2010). Psychodynamische Psychotherapie (translated title: Psychodynamic Psychotherapy). Stuttgart: Schattauer.

Schore, A. N. (2003). Affektregulation und die Reorganisation des Selbst (English title: Affect Regulation and the Repair of the Self). Stuttgart: Klett-Cotta.

Schultz-Venrath, U. (2013). Lehrbuch Mentalisieren (translated title: Textbook on Mentalization). Stuttgart: Klett-Cotta.

Sharaf, M. (1994). Wilhelm Reich: Der heilige Zorn des Lebendigen - Die Biografie (English title: Fury on Earth - A Biography of Wilhelm Reich). Berlin: Simon \& Leutner.

Tasche, J. (2016). Körperpsychotherapie zwischen Bioenergetik und Psychoanalyse (translated title: Body-Oriented Psychotherapy between Bioenergetics and Psychoanalysis). Wiesbaden: Springer.

Tasche, J., \& Weber-Steinbach, R. (2018). Bioenergetik als mentalisierende Körperpsychotherapie-Beiträge zum psychodynamischen Verständnis einer leibhaften Affektivität (translated title: Bioenergetics as a Mentalizing Body-Oriented Psychotherapy - Contributions to a Psychodynamic Understanding of an Embodied Affectivity). Göttingen: Vandenhoeck \& Ruprecht.

Taubner, S. (2016). Konzept Mentalisieren (translated title: The Mentalization Concept). Gießen: Psychosozial-Verlag. 
Jens Tasche

Trauma (Psychology) (2020). In Wikipedia (German). Online publication: https://de.wikipedia.org/ w/index.php?title=Trauma_(Psychologie)\&oldid=197000113 (retrieved February 9, 2020).

Tyson, P., \& Tyson, R. (2012). Lehrbuch der psychoanalytischen Entwicklungspsychologie (English title: Psychoanalytic Theories of Development - An Integration). Stuttgart: Kohlhammer.

William, L. L. et al. (2006). Die Ausbildung von psychiatrischen Assistenzärzten in mentalisierungsgestützter Behandlung (translated title: Training of Psychiatric Assistant Doctors in Mentalization-Based Treatment). In J.G. Allan \& P. Fonagy (Eds.), Mentalisierungsgestützte Therapie (English title: Handbook of Mentalization-Based Treatment). Stuttgart: Klett-Cotta.

\begin{abstract}
About the author
Jens Tasche is a certified social worker (German Diplom), Certified Bioenergetic Analyst, author of the book Körperpsychotherapie zwischen Bioenergetik und Psychoanalyse (English translation: Body-Oriented Psychotherapy between Bioenergetics and Psychoanalysis) and editor of the book Bioenergetik als mentalisierende Körperpsychotherapie (English translation: Bioenergetics as a Mentalizing Body-Oriented Psychotherapy) together with Reinhard WeberSteinbach. He conducts his own practice as a body-oriented psychotherapist, supervisor, coach and trainer in Berlin (Germany). His main interest lies in possible connections between the vitality of the bioenergetic method and the differentiation of the psychodynamic/psychoanalytical framework.

jens.tasche@t-online.de
\end{abstract}

